\title{
Re-packaging old policies? 'Abenomics' and the lack of an alternative growth model for Japan's political economy
}

\section{Saori Shibata}

To cite this article: Saori Shibata (2017) Re-packaging old policies? 'Abenomics' and the lack of an alternative growth model for Japan's political economy, Japan Forum, 29:3, 399-422, DOI: 10.1080/09555803.2017.1284143

To link to this article: https://doi.org/10.1080/09555803.2017.1284143

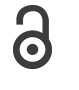

(C) 2017 The Author(s). Published by Informa

UK Limited, trading as Taylor \& Francis Group

Published online: 17 Feb 2017.

Submit your article to this journal $₫$

Шll Article views: 1643

View Crossmark data \lceil

Citing articles: 1 View citing articles $\sqsubset$ 


\title{
Re-packaging old policies? 'Abenomics' and the lack of an alternative growth model for Japan's political economy
}

\author{
SAORI SHIBATA
}

\begin{abstract}
Abenomics' has continued to attract the attention of both the national and international media and a broad range of scholars. There are different and contested views of Abenomics and its impact upon the Japanese economy. This article argues that those more Keynesian-style remedies that form part of Abenomics have not been able to address Japan's longer-term problem of weak demand, especially in terms of private consumption. This is in large part due to the liberalising measures that also form part of Abenomics, and which are incompatible with the Keynesian remedies pursued. Whilst Abenomics has the potential (at least in the short-to-medium term) to improve the profitability of Japanese businesses, in the absence of a corresponding move to redistribute corporate wealth to labour, Abenomics also represents a hazard to future economic growth in Japan.
\end{abstract}

Keywords: Abenomics, political economy, monetary policy, Japan, quantitative and qualitative easing, structural reforms, labour

\section{Introduction}

Since Prime Minister Abe announced his strategy to revive Japan's economy in 2013 the term 'Abenomics' has continued to attract the attention of both the national and international media and a broad range of scholars. Discussions have tended to vary in terms of the degree of support voiced for Abenomics. Many of the early observations made in the national and international media were positive, noting especially the boost to stock prices and the depreciation of the yen. Evaluations have tended subsequently to divide into three groups. The first group of commentators have praised Abenomics, highlighting the effects of the expansionary monetary policy upon expected inflation, the resultant increase in 
stock prices and general increase in corporate profits, and the increased rate of employment and level of public consumption (IMF 2013, Hausman and Wieland 2014). A second group of commentators, whilst broadly supportive of Abenomics, have proposed a number of revisions, including the non-implementation of the planned consumption tax increase (Kataoka 2014, Takahashi 2014, Krugman 2014), the establishment of a fund for SMEs (Krugman 2014, Yoshino and Taghizadeh-Hesary 2014), the increase in the productivity of firms and investment in human capital and ICT capital (Fukao 2013), and/or much further implementation of liberalisation (Fukao 2013, Katz 2014, OECD 2015a). The third group, in contrast, have been more critical in their evaluation of Abenomics, focusing especially on the 'third arrow' - that is, Abe's longer-term structural reform strategy - emphasising the way in which the first and second arrows contribute to the expansion of corporate profit, whilst the third arrow will undermine and destabilise those most vulnerable within Japan's labour market and wider society. As such, Abenomics is depicted as a deepening of precarity and inequality within Japanese society (Ueda 2013, Wolf 2013, Ito 2014, Roberts 2014).

This article engages with the debate regarding the merits of Abenomics. It locates Abenomics within the historical transformation of Japan's socio-economic institutions. It goes on to examine the extent to which Abenomics has contributed to the growth or non-growth of Japan's economy, whether Abenomics represents an alternative growth model for the Japanese economy, and the key challenges that Abenomics faces. The article presents an overview of the historical transformation of Japan's political economy, arguing that Abenomics is a mix of both Keynesian and neoliberal remedies, the effects of which are both limited and not as unconventional as some commentators have emphasised (cf. Takahashi 2014, Hausman and Wieland 2014). Indeed, Abenomics is not distinctively different from the reforms of Abe's predecessors.

The article also takes issue with the aims of the so-called 'third arrow'; that is, Abe's neoliberal policy package. This, it is argued, poses a threat to the stability of Japan's economy, and especially to its workforce. Those more Keynesianstyled remedies that are included within Abenomics have therefore not sought to address Japan's longer-term problem of weak demand, especially in terms of private consumption. Whilst Abenomics has the potential (at least in the short-tomedium term) to improve the profitability of Japanese business, without witnessing a corresponding move to redistribute corporate wealth to labour, Abenomics also represents a hazard to future economic growth in Japan and therefore it appears unable to cure its underlying longer-term problems.

The article is divided into three parts, the first providing an overview of the historical transformation of Japan's political economy between the 1980s and 2000s. The second part introduces the views, narratives and current debates over Abenomics. The third section seeks to provide an analysis and examination of Abenomics in the context of the historical transformation of Japan's socio-economic institutions. The paper argues that Abenomics, which is a mix of 
Keynesian remedies and liberalisation, fails to address the current problems of instability in the labour market in Japan, and the lack of adequate policies that can achieve a certain degree of compromise between the government/capital and labour may harm the potential benefits of Abenomics.

\section{Coordination and liberalisation? The transformation of Japan's political economy between the 1980 s and 2000 s}

The institutions that form the Japanese economy have experienced a significant level of change over the last 30 years. This includes the labour market, financial market, corporate governance, models of firms, the form of the Japanese state, and Japan's trade relations. Many refer to the bursting of the bubble economy in the early $1990 \mathrm{~s}$ as a turning point in terms of change in the Japanese political economy (Vogel 2006, Boyer et al. 2012, Isogai 2012, Uemura 2012, Yamada and Hirano 2012, Fukao 2013, Lechevalier 2014, Schiff 2015). These commentators also highlight the significant changes witnessed in the Japanese economy. This section explains key socio-economic changes between the 1980s and 2000s, paying attention to the process of institutional transformation (especially those institutions that govern the capital-labour relations that constitute Japan's model of capitalism) in order to provide a context within which we can locate Abenomics.

Japanese capitalism has experienced a trajectory of liberalisation, combined with a decline in economic growth, an institutional crisis and a lack of coordination between institutions and between actors over the past thirty years (Lechevalier 2014, Tiberghien 2014). The institutional change has been remarkable and resulted in a trend of (neo-)liberalisation. The earlier 'classic' Japanese system was characterised by coordination and a certain degree of consensus. Coordination in Japan's political economy had benefits and limits. Benefits included the diffusion of technical and organisation innovations. For instance, in the case of Toyotism (Boyer et al. 1998, cited in Lechevalier 2014, p. 7), the specific mode of production was spread to group-firms and firms in other countries. Moreover, coordination acted to reduce fluctuations in a firm's profits as well as at the macroeconomic level (Lechevalier 2014, p. 7). Similarly, networks between firms and between firms and banks enabled many firms to share information, risk, and sustain long-term relations. This type of coordination can act to stabilise production and capital-labour relations, leading to less fluctuations in a firm's profits and employment status (Hall and Sosckice 2001).

Coordination in the classic Japanese economic model also allowed for negotiated outcomes that acted to limit the growth of inequality (Lechevalier 2014, p. 7). For instance, the Japanese labour market witnessed an eradication of industrial unions and a move toward more cooperative union leaders and enterprise unions - a process that was complete by around the time of the 1970s (Jeong and Aguilera 2008, p. 119). In this type of coordinated labour market, 
capital and labour regularly acted to form compromises, to a greater extent than in more free market economies. Indeed, one of the trademarks of the post-war Japanese model of capitalism is the prevalence of long-term employment (Estévez-Abe 2008, p. 171), which provided social security (Schaede 2004, p. 283). The government set up this policy through a series of court decisions that made it almost impossible for a company to lay off workers (Schaede 2004, p. 283). As a result, by the 1970 s long-term employment had become an institutionalised system underpinned by employment legislation (Schaede 2004, p. 283). Japan's labour market therefore used to be characterised by its stability, including long-term relations between employers and employees, a senioritybased wage system, and enterprise unionism that enabled relatively stable capital-labour relations (Rebick 2005, Witt 2006, Weathers 2008, Imai 2011, Lechevalier 2014, Tiberghien 2014, Uemura and Tahara 2014). This is not to say that all labour relations were harmonious, but discontent among workers was pacified to a considerable extent.

Moreover, the role of the state contributed to the degree of coordination that marked Japan's classic economic model. The level of deregulation and liberalisation in the market, which can be affected by the state has a significant impact upon the type of market economy. In the case of Japan, the state is generally considered to intervene in the market more than it does in more liberal market economies. This model of the Japanese state developed during the post-war period and leading up until the 1980s, and was commonly termed a developmental state. Until the mid-1970s, the Japanese government protected key domestic manufacturers from international competition by adopting a high wall of import tariffs (Rosenbluth and Thies 2010, p. 83). The state also used its public spending and increased labour demand to support core industries, including the construction industry, providing employment opportunities (Estévez-Abe 2008, p. 186). The Japanese state played a significant role in terms of the coordination of institutions and negotiation in the market.

However, coordination, which characterised 'classic' Japanese capitalism, has been continuously challenged from the late 1980s onwards following the entry of the Japanese economy into a period of slow growth. Having experienced overaccumulation, Japanese capital sought to restructure its mode of production in order to increase the rate of profit. This was accompanied by a process of deindustrialisation from the 1990s onward, whereby we witnessed a shift from manufacturing to the service industry (Uemura and Tahara 2014). This trend of deindustrialisation also advanced the process of flexibilisation of labour, as it saw the expansion of the proportion of non-regular workers in the labour force. This was therefore a key change in capital-labour relations in Japan, as stability and long-term relations were (and continue to be) weakened significantly.

Along with the change in industrial structure and Japan's slow economic growth, the role of the state in terms of its coordinating role within Japan's economy also changed from the late 1980s onwards. That is, the state took an active 
role in promoting flexibilisation within the labour market. The introduction of the Worker Dispatching Law in 1985 was a key initial trigger for the flexibilisation and casualisation of labour in Japan. This law was launched by the Nakasone government (1982-1986), in order to deregulate and liberalise the Japanese labour market as a part of a project of neoliberalisation. Similarly, the Koizumiled government (2001-2006) took a lead in accelerating the process of neoliberalisation in the labour market. It also revised the Worker Dispatching Law in 2003, and the Labour Standard Law in 2004, and shifted risks inherent to employment liberalisation onto non-regular workers whilst preserving employment security for regular workers (Yun 2010, pp. 5,9). The amendment of the Labour Standard Law in 2004 also saw an additional clause being adopted, which recognised employers' right to dismissal (Vogel 2006, p. 81, Yun 2010, p. 12). This amendment also weakened the level of stability in capital-labour relations, making the Japanese labour market ever more unstable, especially for nonregular workers.

When this amendment was proposed in the advisory council, Rengo, the leading national unions' association, and union representatives, were unable to exercise a veto because of divisions between the unions on this issue (Hamaguchi 2003 , cited in Watanabe 2012, p. 29). Some labour unions opposed deregulation, whereas others in the automotive and electronics industries (which possessed an influential position in Rengo) welcomed the proposal (Hamaguchi 2003 , cited in Watanabe 2012, p. 29). This amendment further enhanced the flexibility of employment practices facing non-regular workers, without introducing appropriate protections for them. These amendments, introduced in the early 2000s, consolidated existing inequalities between regular and non-regular workers (Yun 2010, p. 9). The Koizumi Government reduced employment protection for non-regular workers whilst preserving it for core regular workers (Vogel 2006, p. 81). It visibly favoured capital over labour, heightening social tensions and class antagonism. This represented a significant change to the way in which negotiation and coordination had been conducted by the Japanese state.

This change was accelerated further still in the late 2000s. Non-regular workers have experienced an exacerbation of their precarious employment status in the aftermath of the Global Financial Crisis, as well as following the Fukushima disaster in March 2011. Many firms conducted large-scale dismissals of non-regular workers after the 2007-2008 financial crisis as well as small-scale but frequent dismissals of non-regular workers. For instance, 270,000 non-regular workers lost their jobs during this period due to either dismissals before their contracts expired or to the termination of contracts (Ministry of Health, Labour and Welfare 2010, p. 16). Between 2007 and 2009, involuntary job losses reached 790,000 (compared with only 480,000 dismissals during the Asian Financial Crisis of 1997-1999, and 490,000 between 2000 and 2003) (Ministry of Health, Labour and Welfare 2010, p. 14). Workers had to pay the cost of worsened business conditions, as employers exerted their domination over employees. The 
long-term unemployment rate (the ratio of the unemployed over one year amongst the unemployed) hit its record-high of 38.7 per cent in 2011 in the aftermath of the Fukushima disaster (Ministry of Health, Labour and Welfare 2013, p. 9). Corporate elites adopted numerous measures to cut labour costs and restructure capital-labour relations, reasserting their dominance and authority over the working class. Labour has therefore been placed in a more precarious and impoverished status, demonstrating the increasingly antagonistic nature of capital-labour relations in Japan (Shibata 2016).

Japanese capitalism has therefore experienced stagnation since the bursting of its bubble economy, driving firms to restructure in order to regain profit rates and productivity. This has also triggered flexibilisation of labour markets and has been destabilising long-term capital-labour relations. The Japanese government has also changed its role in the sense that it intervened in the market to liberalise and deregulate in favour of capital. The level of coordination and negotiation in the Japanese model of capitalism has therefore been undermined from the late 1980s onwards. This article now examines how the current project of Abenomics fits within this broader transformation of Japanese capitalism.

\section{Abenomics: contested economic policies}

Abenomics, since its start in 2013, has attracted much attention. The effects of Abenomics, particularly its monetary and fiscal policies, have been debated frequently among many commentators (see for instance, Krugman 2013, Ueda 2013, Fujiwara et al. 2014, Hausman and Wieland 2014, Yoshino and Taghizadeh-Hesary 2014, Roberts 2014, 2015, Takahashi 2014, Schiff 2015). This section will introduce the so-called 'three arrows' of Abenomics and the debates that have been engaged in on the topic. It will also examine how Abenomics contributes to Japan's current economic model and seek to explain the preliminary effects of Abenomics upon the Japanese economy.

\section{Bold monetary policy (the first arrow)}

The first arrow of Abenomics was launched in 2013 as a form of 'quantitative and qualitative easing' (QQE) in order to increase the monetary base in the Japanese market (Cabinet Office 2014b; Fujiwara et al. 2014). In this sense, monetary policy is being used according to Keynesian prescriptions, viewed as a necessary remedy during economic recession (see, for instance, Krugman 2013). The bold monetary policy here refers to the increase in the monetary base by the Bank of Japan through its 'quantitative easing, forward guidance of interest rates, and/or future asset purchases' (Ueda 2013, p. 253). PM Abe also instructed the Bank of Japan (BOJ) to increase its inflation target to 2 per cent and engage in unlimited easing (Hausman and Wieland 2014, p. 2). 
The success of quantitative easing depends on whether this can change expectations of markets and induce change in agents' perceptions of monetary policy (Fujiwara, et al. 2014, p. 4). As soon as the announcement of the monetary policy package was made on 4 April, JGB yields rose, stock prices increased (by 20 per cent in early June) and the Japanese yen depreciated against the dollar by 10 per cent (Ueda 2013, p. 263). We also witnessed an increase in GDP in 2013 to an annualised rate of 3 per cent on a quarter-on-quarter basis, an improvement in exports due to the yen's depreciation, and an increase in the CPI (consumer price index) from negative to over 1 per cent (Uchida 2014, p. 249). However, the main benefits of the widely praised monetary policy, namely the increase in stock prices, have been led by foreign investors via their aggressive buying of Japanese stocks and selling of Japanese yen, not by domestic investors (Ito 2014, p. 108, Katz 2014, Fukuda 2015). The limited level of domestic investors' participation thus also implies that domestic investors remain sceptical about the effects of Abenomics.

Moreover, the BOJ Governor Kuroda's announcement of his intention to increase inflation to 2 per cent in two years temporarily triggered an increase in consumer prices (up by 1.3 per cent from the previous year). Hausman and Wieland (2014) argue that this monetary policy brought about the rapid growth of the broad money supply and changed expectations towards lower future real interest rates, resulting in increased credit demand, which further creates money in the banking system (Hausman and Wieland 2014, pp. 24-25). Due to this, the current monetary policy under Abenomics is viewed as different from previous experiments with monetary policies in 2001 and 2006 (Hausman and Wieland 2014, pp. 23-24). However, inflation expectations still remained around 1 per cent without much abrupt impact (Fujiwara et al. 2014, p. 6). This inflation is even considered to have occurred mainly due to a 25 per cent drop in the value of the Japanese yen, which raised prices on imports (Katz 2014). The impact of the monetary policy upon inflation seems to be modest. This is important because Kuroda's hope is that inflation would trigger more consumption and that this increase in spending would encourage firms to increase investment and therefore jobs (Ito 2014, Katz 2014).

Furthermore, this monetary policy initially increased the consumer confidence index from around 40 per cent in January 2013 to roughly 45 per cent in July 2013. However, this index dropped from 45 per cent to around 38 per cent in January 2015 (Cabinet Office 2015d). With a limited success in terms of inflation and due to a newly introduced tax hike in April 2014, the effect of monetary policy has been dampened, generating only modest change.

Reflecting the rise in stock prices and the depreciation of the Japanese yen, consumer spending initially 'pushed first quarter economic growth up 3.5 per cent annually and remained strong in the second quarter of 2013' (Fukuda 2015, p. 2). However, this new positive trend in the market did not last long as Japanese consumers appear to have acted contrary to expectations. Indeed, the data show that the expectation of price increases actually resulted in Japanese consumers spending 
less since the mid-2013, contrary to Kuroda's expectation (Katz 2014). This may not be so difficult to deduce from Japan's economic condition, whereby we have witnessed a decline in labour's share of income (Aoyagi and Ganeli 2015, p. 224) and only a small rise in wage among regular workers but a decrease for non-regular workers. For instance, the monthly wage of regular workers increased from 201,694 yen in 2012 to 404,720 yen in 2013, whereas that of non-regular workers decreased from 97,177 yen in 2012 to 96,644 yen in 2013 (Ministry of Health, Labour and Welfare 2014, p. 36, 2015). The wages of regular workers in May 2015 increased by 0.6 per cent in comparison with the previous year, whereas those of non-regular workers decreased by 0.7 per cent (Gekkan Kinrou Toukei Chousa May 2015), increasing the wage disparity between regular and non-regular workers. Further, we have not witnessed increases in secure and long-term jobs. As discussed above, the expansion of the number of non-regular workers under Abenomics has created a situation whereby an increasing number of workers engage in unstable employment with little chance of wage increases. This is a trend that has increased under the current LDP government (Ito 2014, pp. 103-107).

The positive evaluation of Abenomics turned into growing scepticism following the market crash on 23 May 2013 (Fukuda 2015, p. 2). Long-term inflation expectations have not risen substantially. Further, since the Japanese economy was close to a long-term liquidity trap, there was little room for further monetary policy accommodation (Fujiwara et al. 2014, p. 7). Moreover, the level of private investment in the first quarter of 2013 in all industries except the software sector has remained stagnant (the rates of investment growth have been between -0.4 and 0 percent during the FY2014) (Kataoka 2014, pp. 37-39, Oouchi and Ikuta 2015). The bold monetary policy (increased monetary base via the BOJ's largescale purchase of the government bonds), however, has a limited effect on stimulating investment (Ohishi 2015, p. 281). The most recent report by the government highlighted the increase in private investment by 2.7 per cent in certain sectors, including the auto industry, due to the depreciation of the yen. However, the cost of imports rose due to the yen's depreciation and thus dampened the appetite for consumption (Oouchi and Ikuta 2015).

To summarise, in order to exit deflation and regain economic growth, PM Abe introduced Keynesian monetary coordination in order to stimulate inflation expectations, spending and therefore growth. However, as we have seen, changing market expectations has proven difficult, witnessing a failure to achieve inflation, only limited wage increases and a decrease of wages for non-regular workers, all of which has resulted in a continuation of under-consumption.

\section{Flexible fiscal policy (the second arrow)}

The so-called 'second arrow' of Abenomics has been termed 'flexible fiscal policy', and includes two large-scale fiscal packages (OECD 2015a, p. 10, Arslanap 
and Lam 2013). The second arrow has aimed to increase effective demand in order to end deflation and realise a virtuous cycle for the long term by increasing government expenditure (via fiscal policy) (Cabinet Office 2014b, Kataoka 2014 , p. 32). This is expected to increase demand for labour, thereby reducing the number of unemployed, enabling workers to choose better jobs and hence stimulating firms to increase wages for their employees in order to attract workers (Kataoka 2014, p. 32).

The Abe administration proposed an increase in spending of 2 per cent of GDP in its supplementary budget in 2013, although this actually turned out to be much smaller (1 per cent of GDP) (Kitaoka 2013, pp. 3-4, Hausman and Wieland 2014, pp. 2-3). In the mid-term, however, Abe's fiscal policy has sought to achieve a move towards consolidation, particularly to correct fiscal conditions, which have worsened from 2007 onwards and increased to 226 per cent of GDP in 2014 (OECD 2015a, p. 31) (Arslanalp and Lam 2013, p. 23). This high volume of debt has been mitigated by Japan's low interest rates over the last two to three decades due to the large amount of purchases of JGBs by the Bank of Japan, although this low interest rate is not sustainable over the long-term as it renders Japan vulnerable to increases in interest rates (OECD 2015a, pp. 31-32). In 2013, the Abe-led government presented its fiscal strategy to halve the primary deficit of central and local governments, from 6.6 per cent of GDP in FY 2010 to 3.3 per cent by FY 2015, and to achieve a surplus by FY 2020 (OECD 2015a, p. 32). However, we have not witnessed much progress in these goals, rather seeing a worsening of public finances, particularly after the Great East Japan Earthquake in 2011, which required the government to spend about 5 per cent of GDP, including a 10.3 trillion yen (2.2 per cent of GDP) fiscal package in 2013, as well as a 5.5 trillion yen package in 2014 (OECD 2015a, pp. 32-33). The second arrow of Abenomics therefore stands on shaky ground in the sense that any fiscal stimulus has a finite limit created by the longer-term need to tackle the fiscal deficit and large amount of public debt.

As part of its attempt to improve the public finances, the Abe-led government increased consumption tax from 5 to 8 per cent in April 2014. This increase was to be spent on childcare, pensions, healthcare and social insurance (OECD 2015a, p. 33). However, this tax hike was not appreciated by Japanese consumers, prompting negative economic growth due to stagnating consumption (Harding 2015c). This negative impact of the tax hike upon the Japanese economy was criticised by many observers who argued for the importance of inflation or a stronger economic recovery before undertaking actions to achieve fiscal consolidation (Kataoka 2014, Takahashi 2014, Krugman cited in Harding 2015c). In spite of these criticisms, some economists (Hausman and Wieland 2014) emphasised the importance of Abenomics and viewed it as the right policy. However, within the Abe administration, there seems to be a divide between two camps: one camp, particularly in the Ministry of Finance, prefers spending cuts; whereas the other camp, in the Cabinet Office, has determined to prioritise 
economic growth over fiscal consolidation (Harding 2015a). The goal of fiscal balance has therefore been hampered by internal divisions within the Abe-led government, as well as due to the dilemma created by the sense that the increase of consumption tax is both unavoidable but also likely to dampen the effect of fiscal policy and consumer spending.

Flexible fiscal policy has also more recently turned into tightened fiscal policy due to the tax hike and the end of the fiscal stimulus packages (Harding and Inagaki 2015b). The tax hike was arguably introduced too early and put the Japanese economy back into recession in spring 2014, as households were reluctant to increase spending as prices rose as a result of the tax increase. In sum, the second arrow of Abenomics has been faced with contradictory pressures created by the need to increase public spending to stimulate the stagnating economy, at the same time as needing to limit spending due to adverse fiscal conditions. This dilemma has perhaps been most evident in the debate surrounding the recent planned increase in consumption tax.

\section{Growth strategy (the third arrow)}

The third arrow is a growth strategy, consisting of structural reforms, whereby the government pledges that it will seek to strengthen the competitiveness of domestic firms, overcome energy constraints, and enhance the innovation platform (Hausman 2014, p. 3, Yoshino and Taghizadeh-Hesary 2015, p. 8). The third arrow of structural reforms is also viewed by the Government as the most important for the success of Abenomics and Japan's long-term economic growth (Schiff 2015, p. 25, Szekeres 2015, p. 400). In setting out these reforms the Abe administration outlines ten key reforms, which include its aim to promote businesses by reducing corporate tax, improving corporate governance, encouraging venture capital and stimulating innovation through technology (Cabinet Office 2015e). These reforms also seek to reinvigorate the Japanese labour market by promoting women's participation, further flexibilising working practices, and attracting high-skilled foreign workers. Reforms further seek to enhance the liberalisation of the agricultural industry by emphasising the necessity of the participation in the Trans Pacific Partnership (TPP). The third arrow also seeks to create an environment for new growth sectors including energy, environment and health care services and its integration with Asia (Danninger and Steinberg 2015, p. 188). With these ten key reforms, the growth strategy aims to a create a 'ripple effect' across the nation and achieve two further goals: local revitalisation and the innovation of small and medium-sized enterprises (SMEs), and structural reforms in regional economies (Cabinet Office 2014a). Some of the measures set out in this strategy aim to benefit the Japanese economy. For instance, promotion of innovation and R\&D in the workplace has been viewed as important for Japanese firms as well as employees. In fact, some Japanese automakers are increasing 
investment in new fields such as fuel-cell vehicles, with research and development expenditures reaching a record high (approximately JPY 2.5 trillion planned for FY2014) (Cabinet Office, 2015a).

However, there remain some concerns over these strategies, particularly with regard to the effectiveness of corporate tax and the further flexibilisation of the labour market. The first strategy of enhancing corporate governance is aimed at shifting Japanese corporate governance towards an Anglo-Saxon model by encouraging firms to accommodate more outside directors (Cabinet Office 2015e). This is aimed at weakening networks, including keiretsu, between Japanese firms. The Abe-government also aims to reduce corporate tax, which has already been reduced by 2.4 per cent since April 2014, with a target to reduce it to below 30 per cent in 2016 (Cabinet Office 2015a, p. 2, 2015b). However, the reduction of corporate tax was conducted in the 1990s, contributing in part to the deterioration of Japan's public finance (Ito 2014, p. 84). Moreover, the most profitable American firms were at that time subjected to a high corporate tax rate $(40 \%)$, suggesting that the reduction of corporate tax does not necessarily guarantee the improvement of Japanese firms' productivity (Dourille-Feer 2015, p. 24).

Perhaps the most problematic aspect of the 'third arrow', however, is the goal of 'flexible working practices'. Regardless of the increasing level of poverty in Japan, which ranks sixth out of thirty-five developed countries in terms of relative income poverty (OECD 2015b), rather than focusing on measures to prevent precarious forms of employment, the initiatives chosen by the Abe administration have acted to create a further flexibilisation of working practices. PM Abe, somewhat paradoxically, directly appealed to firms to increase the wages of employees whilst at the same time implementing measures that would ensure the flexibilisation of the labour market. PM Abe's appeal will not directly increase wages but the enhancement of flexibilisation of working hours will lead to the reduction of payment for overtime and/or long-working hours without any monitoring mechanism. For instance, in terms of working hours, the structural reforms being pursued aim to 'enable flexible working practices', and improve the 'talent pool', representing an initiative to develop a more creative working practice where performance is evaluated rather than the number of working hours (Cabinet Office 2014b, p. 44). To concretely implement this initiative, there is a proposal to reform the Discretionary Working System, which allows 'creative work habits and more people to have flexible working practices' (Cabinet Office 2014 b, p. 44). However, PM Abe had to withdraw this proposal due to strong criticism within the LDP, from the opposition parties and from labour, highlighting the inhibiting effect of popular discontent upon the scope for labour market reforms.

In a nutshell, what we have been witnessing as a result of flexible labour market reforms is the weakening of some of the working practices that were central to the 'classic' Japanese model, including the seniority wage system and stable 
employment system, and the transformation of those practices toward more performance-based and more competitive employment practices. This consolidates trends in policymaking that were already begun in the 1990s. This move towards flexibilisation is heralded by Abe himself, in that he boasts of his achievement of 'fundamental policy change from excessive employment stability to labour fluidity' (Cabinet Office 2015a, p. 3). The third arrow of Abenomics thus aims to deregulate and liberalise the labour market.

In addition to the reforms detailed above, the government also implemented reforms to the way in which new information about jobs is announced by the public employment bureau (Hello Work) to temp agencies. Some unionists, such as the chairman of Zenroren (the second largest trade union confederation in Japan), have argued that this reform would increase the range of job opportunities available in temp agencies, continuing to provide precarious forms of employment, and leading to increased profits for temp agencies but not for workers (Zenroren 2015). Despite the heightening criticisms of precarious employment held by non-regular workers (these criticisms were particular demonstrated in the event of Hakenmura (Temporary Camp for the unemployed and non-regular workers)) in December 2008, the Abe administration appears to be further accelerating the liberalisation and flexibilisation of the labour market, to the overall benefit of capital.

Furthermore, as part of the structural reforms, the Abe administration set a target to establish an improved 'labour dispute resolution system' by the end of 2015 (Cabinet Office 2014b, p. 46). This target has been set up in order to make Japanese employment practices more transparent, especially for foreign countries. The government is seeking to 'clarify ... the relationship between the amount of money paid to resolve disputes and various factors' (Cabinet Office 2014 b, p. 46). Regarding this, the deregulation committee (Kisei Kaikaku Kaigi) started to suggest payment for mediation, labour tribunal decisions, and conciliation. This proposal has raised concerns amongst unions since it has the potential to weaken the effect of Japan's employment practices, which generally require four conditions that firms had to meet to conduct dismissal of their employees (Syutoken Nakama Union 2015). These four conditions imposed upon employers have in the past contributed to the low level of unemployment in the Japanese labour market. However, it is also clearly an intention of the Abe administration to lower this standard of employment regulation in Japan and shift the labour market toward a highly flexible market, whereby employers will be allowed to dismiss workers more freely as long as they pay certain costs for mediation and labour tribunal decisions.

PM Abe's attempts to encourage firms to increase wages is motivated in part by the desire to create a level of consensus between employers and employees. The new growth strategy therefore appears to include some policies that favour companies (e.g. the reduction of corporate tax and a regulation that allows more flexible working hours), but also seeks to ensure that the less competitive 
industries (including the agricultural sector and small- and medium-sized firms) and local economies do not lose out too much. However, the increase in consumption tax and the decrease of corporate tax tend to favour the interests of capital, to the cost of workers. Reforms suggested in the agricultural sector have also been broadly similar to the preceding DPJ government's 'new growth strategy' in the way that both strategies seek to develop the competitiveness of the agricultural sector. The Cabinet Office of Japan reports the achievement of Abenomics, including wage increases and more female workers' participation in the labour market (Cabinet Office June 2015a). However, the increase in flexible working hours, the decrease of wages of non-regular workers, and the absence of measures to reduce the number of non-regular workers, each contribute to what appears to be a longer term attempt to ensure a destabilisation of the position of workers within the Japanese labour market. These policies represent a further acceleration of neoliberalism, which, as noted above, began during the 1990s in Japan under the Hashimoto administration (1995-1998) and Koizumi administration (2001-2006) (Shibata 2016). These policies have the potential to further weaken labour's position and dampen the potentially positive effects of Abenomics. Moreover, Abenomics largely fails to benefit small- and medium-sized enterprises (SMEs) due to 'higher energy costs and other intermediate imported goods costs caused by depreciation of the yen' (Aoyagi and Ganelli 2015, p. 225) which represents an additional threat to the Japanese economy since SMEs account for 70 per cent of employees in Japan (Aoyagi and Ganelli 2015, p. 225).

Japan's GDP data suggests that its economy is struggling under Abenomics. Japan's economy grew at an annualised pace of 2.4 per cent in the first quarter of 2015 and the stock market surged with a growth in GDP forecast of 1.5 per cent. However, these increases were said to be due to a large-scale build-up in inventories. Adjusting for these factors, the actual economic growth was only 0.4 per cent (Harding 2015b). Furthermore, the Japanese economy only witnessed a moderate recovery in consumer and business spending despite the fact that the Abe-administration and the BOJ implemented a significant level of economic stimulus. Consumer spending remains stagnant due largely to the increased sales tax. Further, more than 38 per cent of the workforce are employed as non-regular workers, and thus without increases to their wages, undermining any attempt to stimulate consumption.

In sum, whilst the Keynesian remedies of the first and second arrows of Abenomics (monetary and fiscal policies) had a limited impact upon growth. Liberalisation, encouraged by the third arrow, has further destabilised the labour market, resulting in a situation whereby the effects of the growthfocused elements of the three arrows that form Abenomics are constrained further still. 


\section{Abenomics, coordination and liberalisation: an alternative growth model or repackaging old policies?}

This section seeks to examine the extent to which Abenomics can be considered a coherent and alternative economic growth model, or whether it represents merely a repackaging of old policies. The article argues that Abenomics is a mix of coordination and liberalisation, as was the case in with earlier attempts to reform the Japanese economy, including those undertaken by the Koizumi (2001-2006), Hatoyama (2009-2010), Kan (2010-2011), and Noda (2011-2012) administrations, but in this instance with much stronger emphasis placed upon the liberalisation and deregulation of the Japanese economy. The article further argues that the mere repackaging of old policies will not result in improved prospects for economic growth, but rather will increase discontent, especially amongst precarious workers, which itself represents an impediment to growth.

Existing analyses of Abenomics can be roughly divided into three groups. The first group, which consists of both scholars and some of the key international organisations, broadly agree that the bundle of policies that constitute Abenomics is likely to improve Japanese economic growth, but also suggest a number of reforms to the policies, each of which seeks to further extend the degree to which the emphasis is on liberalisation of the economy. For instance, Fukao (2013) encourages the government to liberalise the Japanese market by further establishing free trade agreements and reducing corporate taxes (Fukao 2013, p. 209). Katz (2014) emphasises the importance of improving workers productivity, especially due to Japan having an aging society. He suggests that Japan needs serious structural changes, including the replacement of decaying firms with vibrant ones, and an increase in competitiveness for domestically oriented firms (which are protected from international competition by regulations) (Katz 2014). He also advocates the liberalisation of the Japanese market through the Trans-Pacific Partnership (TPP) and inducing more competition amongst industries such as the dairy market and agriculture. He further criticises the rigidities in the Japanese labour market, emphasising the importance of competition and flexibility in the workplace (2014). Similarly, the OECD urges PM Abe to implement liberalisation urgently (OECD 2015a). Three points in particular are recommended by the OECD (OECD 2015a): (1) slow the trend of decline in the labour force; (2) participate in high-level trade agreements (TPP, Japan-EU Economic Partnership Agreement); and (3) improve the business climate to boost productivity growth (liberalisation of corporate governance, promotion of labour market flexibility, reduction of corporate tax, shift towards a more market-based agricultural system). These recommendations each seek to promote the further liberalisation

of the Japanese economy by prioritising the establishment of a business-friendly environment and integrating the Japanese market more deeply within the international market. In sum, for this group of scholars and international 
organisations, Abenomics is a step in the right direction but could be further improved through greater implementation of liberalising measures.

A second group of commentators is also broadly supportive of Abenomics, but for different reasons. This group, which includes scholars such as Krugman (2013) and Yoshino and Taghizadeh-Hesary (2014), views Abenomics positively on the grounds that it seeks to stimulate demand, inflation (over a sufficiently lengthy period of time) and restore fiscal balance (Yoshino and TaghizadehHesary 2014, p. 24). Regarding the 'third arrow' of Abenomics, this second group welcomes some of the more pro-growth/pro-demand and more interventionist measures, such as the expansion of domestic consumption, attempts to encourage female participation in the labour market, measures to reduce healthcare costs to cope with the aging population, an increase in the share of $\mathrm{R} \& \mathrm{D}$ and education in government expenditure, and improved access to finance for SMEs (Yoshino and Taghizadeh-Hesary 2014). Paul Krugman, for instance, praises Abenomics on the grounds that it improved public expectations, Japan's fiscal outlook and the expectations of Japan's exporters (Krugman 2013). He further claims that PM Abe is making a clear break from a bad orthodoxy and that something remarkable may happen in Japan if the policies of Abenomics succeed (Krugman 2013). This second group is also, therefore, broadly supportive of Abenomics on the grounds that it represents a break with the pro-austerity and pro-liberalisation consensus that has been adopted by most of the political elite across the advanced industrial democracies. As such, Abenomics is viewed positively precisely because it is as unorthodox and unconventional.

There are, therefore, two contrasting views amongst supporters of Abenomics. On the one hand, we see those who are positive about Abenomics on the grounds that it seeks to promote consumption, investment and growth. On the other hand, there are those who believe Abenomics will be successful, provided that it includes a strong commitment to the furthering the liberalisation of Japan. What each of these interpretations misses, however, is that the liberalising elements of Abenomics also act to create insecurity for Japanese workers, whilst at the same time relying upon an expectation that there will be increased consumption - presumably from the very same workers who are experiencing heightened income insecurity. In the absence of sufficient provisions to improve the economic security of Japan's workers/consumers, therefore, it is difficult to see how a renewed social compromise (required to underpin a return to growth) can be constructed. Indeed, such a social compromise would include a set of policies and socio-economic institutions that have the potential to contain social tension and popular discontent (especially that of Japan's growing share of non-regular workers) and generate temporary economic growth. Long-term economic growth cannot be realised without both carrying out wide-ranging reforms (Patrick 2016, p. 8) and addressing declining wages and growing precarity. Non-regular workers, in particular, are vulnerable to declining income and (given that they are a growing proportion of the workforce) therefore represent a significant obstacle to attempts to 
stimulate consumption. In this sense, Abenomics lacks a plan through which to create a much-needed socio-economic compromise that could re-introduce some of the mechanisms of cooperation that underpinned the preceding (more successful) 'classic' model of Japanese capitalism. Without re-establishing such a compromise, moreover, firms will continue to be under pressure to reduce costs in order to be able to compete within increasingly globalising markets; weaker firms (especially SMEs) and industries (especially the agricultural industry), in particular, will be likely to become unsustainable under a heightening level of competition. As we can see, therefore, policies implemented as part of Abenomics contain a number of contradictions that might not have been fully addressed.

In addition to these underlying contradictions, Abenomics also represents (to an extent that has often gone unnoticed) a continuation of policies that have already been adopted by preceding governments, but which have thus far failed to achieve a return to growth within the Japanese economy. On these grounds, therefore, we might be less optimistic that Abenomics is able to restore growth to Japan. In particular, the third arrow of structural reforms in Abenomics shares similarities with policies implemented by the preceding governments of Nakasone, Hashimoto and Koizumi. For instance, former PM Nakasone (19821987) sought to increase the internationalisation of the Japanese economy, including through trade liberalisation (including that of agricultural trade), alongside attempts to achieve a flexibilisation of labour markets, and deregulation of finance (Tiberghien 2014, p. 38). The Nakasone government also sought to encourage wage rises in much the same way as PM Abe has done. The Nakasone government also similarly sought a mix of Keynesian budgetary policies and neoliberal structural reforms. There also exists a strong continuity between the reforms of Nakasone and those of the later Hashimoto administration (19961998), which sought to promote corporate restructuring, and deregulation and liberalisation of the financial market (Tiberghien 2014, pp. 41-42). Hashimoto's reforms intended to increase the competitiveness of Japanese firms and also enhance capital movements, thereby seeking to further integrate the Japanese economy within international markets. As such, the economic reforms of the Hashimoto administration are strikingly similar to many of those that form the ten key policies making up Abe's structural reforms.

The structural reforms that make up the 'third arrow' of Abenomics also consist of changes to existing patterns of corporate governance; aiming to relax regulations and create a business-friendly environment, including through the weakening of keiretsu networks so that foreign firms can be integrated in the market (OECD 2015a). In doing so, the third arrow seeks to create a more open market where foreign firms can do their business and investment more flexibly. By loosening the close keiretsu networks and allowing foreign firms to come into the Japanese market, the third arrow further seeks to stimulate Japanese business and make firms more internationally competitive. Again, these initiatives are not new, in that similar goals have been sought by the administrations of Nakasone, 
Hashimoto and Koizumi, each of whom sought to create a more businessfriendly environment by liberalising the Japanese market, reducing barriers to entry to the market for foreign actors, and lowering corporate tax for domestic and foreign firms. We can also see clear similarities between the structural reforms contained within Abenomics and those specified in the New Growth Strategy 2009, of the DPJ's Hatoyama administration, which included plans to achieve structural reforms in agricultural, IT and human capital, as well as seeking a regeneration of regional economies. That said, one of the key differences between Abenomics and the DPJ's strategy is the focus within Abenomics upon a much more explicit target of liberalisation and deregulation of the market in order to create a business-friendly environment and a more flexible labour market. Abenomics is, therefore, in this sense a re-packaging of old policies, but with a stronger emphasis and focus on liberalisation.

Two problems in particular arise for Abenomics as a result of its somewhat contradictory embrace of liberalisation. First, there exists an inability to produce a renewed social and institutional compromise that would enable the Abe administration to achieve coordinated improvements to Japan's political economy. For instance, in 2014, the government, Keidanren (the Japan Business Federation), the Japan Chamber of Commerce and Industry, the National Federation of Small Associations, and Rengo (the Japanese Trade Union Confederation) reached an agreement to work in cooperation regarding wage increases, wage negotiations and enhancement of productivity and improvement of treatment of non-regular workers (Rengo 2015, p. 16). This initiative, however, has faced considerable obstacles, largely due to the absence of a broader social consensus. In particular, the government has not made sufficient effort to negotiate or build a consensus with the broader network of trade unions that extends beyond the Rengo. This is most clearly shown by the fact that Rengo remains the only union confederation to be included in the negotiations on employment protection in deliberation councils attached to the Ministry of Health, Labor and Wealth (shingikai) (Yun 2016, p. 475). Indeed, a number of criticisms of the government by other union confederations, including that it has failed to sufficiently include other unions and union confederations, have been made. The Abe government has not included non-Rengo unions in its decision-making process, with the absence of unions representing non-regular workers being particularly notable (Ministry of Health, Labour and Weath, 2016). ${ }^{1}$ One noteworthy consequence of this has been the failure of the Abe administration to achieve its stated goal of encouraging firms to raise wages. Abenomics therefore appears to be faltering, both in terms of its efforts to introduce a greater degree of socio-economic coordination and to achieve a greater degree of compromise between different trade unions and different types of workers.

Second, the shift in resources that is taking place from wages to profits, has had a detrimental effect upon consumption and saving patterns. Ito (2014) warns that the Abe government seeks a labour market in which companies are much 
more free to hire and fire at will, can employ non-regular workers with cheap wages, and have no legal obligation to pay overtime (Ito 2014, pp. 62-63). In a similarly critical tone, FT columnist Martin Wolf expressed his concerns over 'excessive private savings' and reported that excessive retained earnings should be lowered via increasing wages and changing corporate taxation (Wolf 2013). Similarly, Yamada and Hirano (2015) highlight the way in which management in Japanese firms has responded to shareholder pressure by providing greater dividends and increasing its own internal reserves, without distributing wealth to workers. From this perspective, the third arrow fails to sufficiently incorporate a broader segment of the economy, that is, its workers. This both acts to deepen discontent amongst workers (who suffer from employment insecurity and stagnating wages) but also (relatedly) acts to contribute to under-consumption. Clearly this is a problem for Abenomics in that one of its central aims is to create a virtuous circle in which we see a mutually reinforcing increase in investment, income and consumption.

Indeed, one of the central problems facing Japan's economy is that Japanese firms have retained and accumulated a high level of cash, which has acted to restrain aggregate demand and potential output growth (Shinada 2012, cited in OECD 2015a, p. 24). Throughout the 2000s, the proportion of cash holdings in the Japanese corporate sector has been much higher than in the corporate sectors in the US and European Union (OECD 2015a, p. 25). This problem could be solved by increasing wages (to stimulate consumption) and/or increasing investment. The net return on capital in Japan has been increasing since the introduction of Abenomics (Roberts 2015), but appeals by the Abe-led government, calling on firms to increase wages for their employees, have not so far been heeded within the business circle, resulting in the continuation of stagnating wage growth in Japan. This perhaps illustrates the limited means by which firms can be persuaded to limit profit-seeking and increase wages (Harding and Inagaki 2015b).

The alternative growth model requires socio-economic institutions that coordinate different interests and can contain discontent among workers and improve precarious workers' conditions. However, Japanese firms do not appear to share their retained earnings through an increase of wages or labour protection. As a result, the government has been further pressured to implement a negative interest rates policy and further quantitative easing. Without addressing contentious issues surrounding workers, and establishing coordination and compromise between capital and labour, Abenomics (which is built upon on liberalisation in a similar way to other political reforms conducted by political elites, including former prime ministers, Hashimoto and Koizumi) faces obstacles to both its implementation and successful execution. PM Abe's recent decision to further postpone his second planned consumption tax rise until October 2019 (another two-year postponement) reflects the fact that Abenomics has not thus far resulted in a stable economic growth model. Indeed, if Abenomics cannot produce a 
stable alternative growth model, able to coordinate capital-labour relations by improving employment conditions, achieving more equity between regular and non-regular workers and employment security, including labour in decisionmaking processes and increasing labour's share of income, it is likely instead to lead to a further increase in the level of discontent, especially on the part of its increasingly insecure labour force. Heightening discontent amongst workers in this sense represents an obstacle to the smooth implementation of Abenomics and in turn undermines the ability to improve the Japanese economy.

\section{Conclusion}

This article examines the existing literature on Abenomics and present a preliminary analysis of the overall aims and outcomes of Abenomics in order to explore the extent to which Abenomics has contributed to the growth or non-growth of Japan's economy. It questions the extent to which Abenomics represents an alternative growth model for the Japanese economy, and highlights the key challenges that Abenomics faces. Whilst some commentators (including Krugman, Posen and Hausman) have tended to highlight the strength of Abenomics on the grounds that it represents an unconventional demand-oriented alternative to the pro-austerity and pro-liberalisation consensus, a second group of commentators and international institutions broadly agree with the liberalising measures that also constitute Abenomics (whilst also pointing to the importance of further strengthening these liberalising measures) (Fukao 2013, Katz 2014, OECD 2015a). Finally, a third group of commentators - with which this paper is most sympathetic - have raised concerns about Abe's structural reforms, on the grounds that they have the potential to destabilise the labour market (Ito 2014, Wolf 2014, Roberts 2015, Yamada and Hirano 2015).

Partly agreeing with the critique made by this third group of commentators, this article argues that Abenomics represents a mix of Keynesian remedies in the financial and monetary policies and neoliberal policies in terms of structural reforms. However, in seeking to both stimulate demand and introduce structural reforms, the potential positive effects of both strategies are limited as a result of their mutual incompatibility. Wage growth has been contained and working conditions surrounding precarious workers remain unstable, leading to stagnating consumption and hence investment. Thus, the attempt to stimulate demand through so-called 'flexible fiscal policy' has been undermined by attempts under the so-called 'third arrow' to create more flexible markets (and especially labour markets), as the latter set of policies have introduced a greater degree of economic insecurity (especially for Japanese workers). Further, Abenomics has been shown to be less different from the policies of previous Japanese administrations than is often assumed. In this sense, Abenomics represents a repackaging of policies, albeit with a stronger emphasis upon liberalisation. Finally, the article shares the concerns expressed by a third group of commentators who point to the 
limited effect that Abenomics is likely to have upon the economy, in particular due to its continued commitment to an unfair and unequal distribution of wealth, to the detriment of Japan's workers, which, in the past, has undermined attempts to achieve a coordinated intervention in Japan's political economy (Ito 2014, Wolf 2014, Roberts 2015, Yamada and Hirano 2015).

Rather than being an alternative growth model, therefore, Abe's neoliberal policy package poses a threat to the stability of Japan's economy. Despite the apparently positive initial impact that Abenomics has had upon stock prices, the reduction of the unemployment rate and the small increase in wages, the 'third arrow' has witnessed an attempt to deregulate Japan's labour market, and in the process imposed a greater burden on labour, and especially the growing number of non-regular workers who have been losing protection and suffering increased precarity in terms of wages and employment status within Japan's changing political economy. Any wage increases that have occurred in recent years have been secured through bonuses or overtime work payments, rather than changes to the standard salary (Ministry of Economy, Trade and Industry 2014), thereby evincing the reluctance of corporations to share any increases in national income or wealth. Workers (and especially non-regular workers) have suffered from stagnating wages, and growing income insecurity as a result of the flexibilisation of labour. Currently, more than 38 per cent of Japan's workforce is employed as non-regular workers. Without the reintroduction of some form of socio-economic compromise, through which this group of workers can be more equitably incorporated into the Japanese economic model, it is difficult to see how Abenomics will be able to generate economic growth in the long term. Those Keynesian-style remedies that are part of Abenomics have not been able to address Japan's longer-term problem of weak demand, especially of the lack of private consumption. Whilst Abenomics has the potential (at least in the short-to-medium term) to improve the profitability of Japanese business, therefore, without witnessing a corresponding move to redistribute wealth to labour, Abenomics represents a hazard to the future economic growth of Japan.

\section{Acknowledgements}

I am grateful for helpful comments from Sébastien Lechevalier, David Chiavacci and the anonymous reviewers.

\section{Disclosure statement}

No potential conflict of interest was reported by the author.

\section{Note}

1. Members of councils (Shingikai meibo) 


\section{References}

Aoyagi, C. and Ganeli, G., 2015. 'Labor Market Reform: Vital to the Success of Abenomics', In: Botman, D.P.J, et al., 2015. Can Abenomics succeed?: Overcoming the legacy of fapan's lost decades. IMF.

Arslanap, S and Lam, R.W., 2013. 'Outlook for Interest Rates and Japanese Banks: Risk Exposures under Abenomics', IM Working Papers, 13/213. Available from: https://www.imf.org/external/ pubs/cat/longres.aspx?sk $=40994.0$ [Accessed January 2016].

Boyer, R., Uemura, H., and Isogai, A., 2012. Diversity and Transformation of East Asian Capitalism. London: Routledge.

Cabinet Office, 2014a. 'Immediate Economic Measures for Extended Virtuous Cycles to Local Economies', December 27, 2014. Available from: http://www5.cao.go.jp/keizai1/keizaitaisaku/ 2014/141227_economic_measures_all.pdf [Accessed 4 September 2015].

Cabinet Office, 2014b. Fapan Revitalization Strategy: Revised in 2014- Fapan's challenge for the future-, Cabinet Office June 24, 2014. Available from: http://www.kantei.go.jp/jp/singi/keizaisaisei/pdf/ honbunEN.pdf [Accessed 4 September 2015].

Cabinet Office, 2015a. "Fapan Revitalization Strategy": Main Achievements to Date and Further Reforms, March 2015. Available from: http://www.kantei.go.jp/jp/singi/keizaisaisei/pdf/seika02 shousaiEN.pdf [Accessed 4 September 2015].

Cabinet Office, 2015b. 'Achievements of the "third arrow" reforms and new measure to be taken', March 2015. Available from: http://www.kantei.go.jp/jp/singi/keizaisaisei/pdf/seika01 gaiyouEN.pdf [Accessed 4 September 2015].

Cabinet Office, 2015c. Abenomics: Decisive Action of Reform $\sim$ There is no alternative $~$ [Abenomikusu: Kaikaku no Dankou $\sim$ Kono Michi shika Nai]. June 2015. Available from: http:// www.kantei.go.jp/jp/singi/keizaisaisei/pdf/kaikakudankouJP.pdf [Accessed 4 September 2015].

Cabinet Office, 2015d. Business Statistics, Consumer Confidence Index, Consumer Perception Indices. Available from:http://www.esri.cao.go.jp/en/stat/shouhi/shouhi-e.html\#cci [Accessed 4 September 2015].

Cabinet Office, 2015e. Revision of Japan Revitalization Strategy $\sim 10$ Key Reforms. Available from: http://www.kantei.go.jp/jp/singi/keizaisaisei/pdf/10challenge02shousaiEN.pdf [Accessed 4 September 2015].

Danninger, S. and Steinberg, C., 2015. Japan's growth challenge: needs and potential. In: Botman, D.P.J, et al., 2015. Can Abenomics succeed?: overcoming the legacy of fapan's lost decades. IMF.

Dourille-Feer, E., 2015. 'Can the Magic of Abenomics Succeed?', CEPIIWorking Paper. Available from: http://www.cepii.fr/PDF_PUB/wp/2015/wp2015-24.pdf [Accessed April 2016].

Estévez-Abe, M., 2008. Welfare and Capitalism in Postwar Fapan. New York: Cambridge University Press.

Fujiwara, I., Nakazono, Y., Ueda, K., 2014. 'Policy Regime Change against Chronic Deflation? Policy option under long-term liquidity trap', AfRC Working Paper, April 2014, Available from: https://papers.ssrn.com/sol3/papers.cfm?abstract_id=2446759 [Accessed January 2017].

Fukao, K., 2013. 'Explaining Japan's Unproductive Two Decades', Asian Economic Policy Review, 8, pp. 193-213.

Fukuda, S., 2015. 'Abenomics: Why was it so successful in changing market expectations?', CIRfE Discussion Papers, CIRJE-F-969.

Hall, P.A. and Soskice, D., 2001. 'An introduction to Varieties of Capitalism', in P.A. Hall and D. Soskice (eds), Varieties of Capitalism: The Institutional Foundations of Comparative Advantage, Oxford: Oxford University Press.

Harding, R. and Inagaki, K., 2015b. Japan wages: Manufacturing consent. Financial Times, 18 February. 
Harding, R., 2015a. 'Japan experts defend Abenomics go for growth' strategy', Financial Times, May 24, 2015.

Harding, R., 2015b. 'Japan GDP data suggest struggle for a momentum', Financial Times, 20 May. Harding, R. 2015c. 'World watches Japan and waits for outcome of Abenomics experiments', Financial Times, 29 March.

Harding, R. and Inagaki, K., 2015a. 'Japan wages: Manufacturing consent', in Financial Times, February 18, 2015.

Hausman, J.K. and Wieland, J. F., 2014. 'Abenomics: Preliminary Analysis and Outlook' Brookings Paper, Spring 2014, pp. 1-63.

Imai, J., 2011. Transformation of Fapanese Employment Relations: Reform without Labour. Basingstoke: Palgrave Macmillan.

IMF, 2013. "Japan: 2013 Article IV Consultation," IMF Country Report No. 13/253, August 5, 2013.

Isogai, A., 2012. 'The transformation of the Japanese corporate system and the hierarchical nexus of institutions', in Boyer et al. (eds.), Diversity and Transformation of Asian Capitalism. London: Routledge.

Ito, M., 2014. Critique of Abenomics: Break Four Arrows [Abenomics Hihan: Yon Hon no Ya wo Oru]. Tokyo: Iwanami Syoten.

Jeong, D.Y. and Aguilera, R.V., 2008. 'The Evolution of Enterprise Unionism in Japan: SocioPolitical Perspective', British fournal of Industrial Relations, 46 (1), 98-132.

Kataoka, G., 2014. Why hasn't Japan's economy recovered yet? [Naze Nihonkeizai ha Fujyo Shinainoka]. Tokyo: Koubunsyashinsyo.

Katz, R., 2014. 'Voodoo Abenomics: Japan's failed comeback plan', Foreign Affairs, 93 (4), 133141.

Kitaoka, S., 2013. 'The Abe Administation: Beyond 100 Days', Asia-Pacific Review, 20 (1), 1-12.

Krugman, P., 2013. 'Japan Steps Out', New York Times, January 13, 2013.

Krugman, P., 2014. 'Japan Through the Looking Glass', New York Times, November 16, 2014.

Lechevalier, S., 2014. Introduction: Seven Japanese lessons on the diversity of capitalism and its future. In: S. Lechevalier, ed. The great transformation of fapanese capitalism. Oxon: Routledge.

Ministry of Economy, Trade and Industry, 2014, 'Chinage Jyoukyou nitsuite', September 2014. Available from: http://www5.cao.go.jp/keizai-shimon/kaigi/minutes/2014/0916/sankou_02.pdf [Accessed 4 September 2015].

Ministry of Health, Labour and Welfare, 2010. White Paper on Labour and Economy 2010. Available from: http://www.mhlw.go.jp/wp/hakusyo/kousei/10/ [Accessed 15 December 2013].

Ministry of Health, Labour and Welfare, 2010. White Paper on Labour and Economy 2010. Available from http://www.mhlw.go.jp/wp/hakusyo/kousei/10/ [Accessed 15 December 2013].

Ministry of Health, Labour and Welfare, 2015. Maitsuki Kinrou Toukei Chousa, Gekkan Genkin Kyuyogaku, May, 2015. Available from: http://www.mhlw.go.jp/toukei/itiran/roudou/monthly/ 27/2705p/2705p.html[Accessed 4 September 2015].

Ministry of Health, Labour and Welfare, 2013. White Paper on Labour and Economy 2013. Available from http://www.mhlw.go.jp/wp/hakusyo/roudou/13/d1/13-1-3_01.pdf [Accessed 4 September 2015].

Ministry of Health, Labour and Welfare, 2016. A list of members of labour deliberation council [Shingikai].

OECD, 2015a. OECD Economic Surveys: Fapan, April 2015. Available from: http://www.keepeek. com/Digital-Asset-Management/oecd/economics/oecd-economic-surveys-japan-2015_eco_sur veys-jpn-2015-en\#page22 [Accessed 4 September 2015].

OECD, 2015b. Relative Income Poverty, In: OECD Income Distribution Database, 2015. Available from: http://www.oecd.org/social/income-distribution-database.htm[Accessed 4 September 2015]. 
Ohishi, K., 2015, Private Investment in Japanese Economy, Nagoya Gakuin Daigaku Ronsyu. Social Science, 51 (4), 281-289.

Oouchi and Ikuta, 2015. Enyasu tanomi, Setsubitoushi ga zouka Kozinsyouhi ha Moriagari Kaku, Asahi Shinbun Digital 8 June, 2015. Available from: http://www.asahi.com/articles/ASH685CQ SH68ULFA01W.html[Accessed 4 September 2015].

Patrick, H., 2016. 'Japan's Abenomics Bumps Along', Occasional Paper Series, no.74, Available from: www.gsb.columbia.edu/cjeb/research.

Rebick, M., 2005. The changing fapanese employment system. Oxford: Oxford University Press.

Rengo, 2015, Rengo chingin report 2014. Available from: http://www.jtuc-rengo.or.jp/roudou/shun tou/2014/shuukei_bunseki/22.html [Accessed 4 September 2015]

Roberts, M., 2014. Abenomics: raises profitability ... and misery, Michael Roberts Blog, 2014, July. Available from: https://thenextrecession.wordpress.com/2014/07/ [Accessed January 2016].

Roberts, M., 2015. 'Japan: the failure of Abenomics', Available from: https://thenextrecession. wordpress.com/2014/10/13/japan-the-failure-of-abenomics/ [Accessed May 2015]

Rosenbluth, F.M. and Thies, M.F., 2010. Japan Transformed: Political Change and Economic Restructuring. Woodstock: Princeton University.

Schaede, U., 2004. 'What Happened to the Japanese Model?', Review of International Economics, 12 (2), 277-294.

Schiff, J., 2015. Abenomics: From the Lost Decade to the Three Arrows. In: D.P.J. Botman, S. Danninger and J. Schiff, eds. Can Abenomics Succeed?: Overcoming the Legacy of Japan's Lost Decades. Washington: IMF.

Shibata, S., 2016. 'Resisting Japan's neoliberal model of capitalism: intensification and change in contemporary patterns of class struggle, British fournal of Industrial Relations, 54 (3), 496-521.

Szekeres, V. 2015. Abenomics:a Way to Accelerate the Fapanese Economic Growth?, Management, Enterprise and Benchmarking in the 21st Century, Budapest, 2015. Available from: https://ideas. repec.org/h/pkk/meb015/397-404.html [Accessed May 2016].

Takahashi, Y., 2014. Counterattack of Abenomics [Abenomics no Gyakusyu]. Tokyo: PHP Kenkyusyo.

Tiberghien, Y., 2014. Thirty years of neoliberal reforms in Japan. In: S. Lechevalier, ed. The great transformation of Fapanese capitalism. Oxon, Routledge.

Uchida, M., 2014. Towards the end of deflation in Japan?: monetary policy under Abenomics and the role of the central bank. Revue de l'OFCE, 135.

Ueda, K., 2013. Response of asset prices to monetary policy under Abenomics. Asian Economic Policy Review, no. 8, 252-269.

Uemura, H. and Tahara, S., 2014. The Transformation of Growth Regime and de-industrialization in Japan. Revue de la régulation, 15, Spring 2014

Uemura, H., 2012. Nihon Keizai no Seidohenka to Seityo Taisei: Aratana Kouzouteki Kikie. In: H. Uni, et al., Kinyu Kiki no Regurashion Riron: Nihon Keizai no Kadai. Tokyo: Syowado.

Vogel, S.K., 2006. Fapan Remodeled: How Government and Industry Are Reforming Fapanese Capitalism. New York, NY: Cornell University Press.

Watanabe, R.H., 2012. 'Why and how did Japan finally change its ways? The politics of Japanese labour-market deregulation since the 1990s', Japan Forum, 24 (1), 23-50.

Weathers, C., 2008. Shunto and the shackles of competitiveness. Labor History, 49(2), 177-197.

Witt, M.A., 2006. Changing fapanese Capitalism: Societal Coordination and Institutional Adjustment. Cambridge: Cambridge University Press.

Wolf, M., 2013. Japan can put people before profits: The key to a better-balanced economy is to take surplus profits away from a corporate oligopoly. Financial Times, 5 February, 2013.

Wolf, M., 2014. Warning from Japan for the eurozone. Financial Times, 4 November, 2014. 
Yamada, T. and Hirano, Y., 2012. 'How had the Japanese mode of regulation changed?', in Boyer, R. Uemura, H. and Isogai, A., 2012. Diversity and Transformation of East Asian Capitalism. London: Routledge.

Yamada, T. and Hirano Y., 2015. Multinationalization of Fapanese firms and dysfunction of companyist regulation. International conference research and regulation: the theory of regulation in times of crises, 9-12 June 10-12, 2015 Paris: Université Paris-Diderot.

Yoshino, N. and Taghizadeh-Hesary, F., 2014. Three arrows of 'Abenomics' and the structural reform of Japan: inflation targeting policy of the central bank, fiscal consolidation, and growth strategy. August 2014, No.492.

Yoshino, N. and Taghizadeh-Hesary, F., 2015. Three arrows of "Abenomics" and the structural reform of Japan: inflation targeting policy of the central bank, fiscal consolidation, and growth strategy, ADBI Working Paper Series, No.492, August 2014.

Yun, J., 2010. Unequal 'Japan: conservative corporatism and labour market. British fournal of Industrial Relations, 48(1), 1-25.

Yun, J., 2016. 'The setback in political entrepreneurship and employment dualization in Japan, 1998-2012', British fournal of Industrial Relations, 54 (3), 473-495.

Zenroren, 2015. Zenroren Non-Regular Workers' Center News [Zenroren/Hiseiki Center News], vol. 27. Available from: http://www.cwac.jp/blog/files/cwac_news27.pdf [Accessed January 2016].

Saori Shibata is at the Universiteit Leiden, Leiden Institute for Area Studies, Arsenaal, Room 1.07, Arsenaalstraat 1, 2311 CT, Leiden, the Netherlands. She may be contacted at s.shibata@hum.leidenuniv.nl. 